\title{
1. What does socialism mean?
}

Under capitalism, man exploits his fellow man. Under socialism it is precisely the opposite.

Eastern European joke from the Communist era ${ }^{1}$

The word socialism is modern, but the impulse behind it is ancient. The idea of holding property in common goes back to Ancient Greece and is found in the Bible. ${ }^{2}$ It has been harboured by some religions and it has been the call of radicals for centuries.

In his 1516 book Utopia, Sir Thomas More imagined a system where everything was held in common ownership and internal trade was abolished. Unlike most other proposals for common ownership before the 1840s, More's Utopia envisioned cities of between 60000 and 100000 adults. It is the first known proposal for what I call big socialism.

Before the rise of Marxism, the predominant vision of common ownership was small-scale, rural and agricultural. It was often motivated by religious doctrine. In Germany in the 1520 s the radical Protestant Thomas Müntzer proposed a Christian communism. From 1649 to 1650, during the English Civil War, the Diggers set up religious communes whose members worked together on the soil and shared its produce. There are other examples of socialism before the word was coined. ${ }^{3}$

This chapter is about the origins, meaning and evolution of the words socialism and communism. They are virtual synonyms, both largely referring to common ownership of the means of production and to the abolition of private property. It is also argued that revisionist attempts to change the definition of socialism have largely failed. This is unlike social democracy, which changed its meaning since the nineteenth century.

\footnotetext{
1 Len Deighton (1964, p. 177) quoted a version of this subversive joke in his novel Funeral in Berlin, where it was told by a fictional KGB colonel, who added: 'we arrested a man for telling that this morning'. Others say the joke was Polish in origin. Like all good witticisms, it probably spread fast. I first heard it in the Soviet Union in 1979.

2 Erasmus (1977), Pipes (2001).

3 Manuel and Manuel (1979), Hodgson (2018, ch. 1).
} 


\section{ORIGINS OF THE WORDS SOCIALISM AND COMMUNISM}

The early nineteenth century saw a flowering of utopian ideas, designed to avoid the ills of industrial capitalism and to create social harmony. Among the most famous proposals were by Claude-Henri de Saint-Simon (1760-1825) and François Marie Charles Fourier (1772-1837). They planned utopian communities using what they believed to be scientific principles of social organization and human psychology. But neither proposed the abolition of private property or the installation of common ownership of the means of production. Neither used the words communism or socialism to describe their schemes. When Frederick Engels labelled these two individuals as 'utopian socialists' he was misinformed or stretching the truth. But many followers of Saint-Simon and of Fourier did eventually promote communities based on common ownership. ${ }^{4}$

Pierre Leroux was one of Saint-Simon's disciples and he claimed to have coined the French word socialisme in about 1832. In English, socialism seems to have emerged earlier. It appeared in November 1827 in the Co-operative Magazine, published in London by followers of Robert Owen, where a writer referred to 'Communionists or Socialists'. It was used in the Poor Man's Guardian in 1833 and moved into more frequent usage thereafter. 'By 1840 socialism was virtually synonymous with Owenism.' 5

For Owen and his followers, socialism meant the abolition of private property. It also acquired the broader ideological connotation of cooperation, in opposition to selfish or competitive individualism. Communal property was seen as its defining institutional foundation. As Owen argued in 1840, 'virtue and happiness could never be attained' in 'any system in which private property was admitted'. He aimed to secure 'an equality of wealth and rank, by merging all private into public property'. 6

In 1840 in Paris, the word communiste appeared in an article by Étienne Cabet and in a pamphlet by Théodore Dezamy and Jean-Jacques

4 Marx and Engels (1962, vol. 2), Manuel and Manuel (1979, pp. 641-75), Hodgson (2018, pp. 62-7).

5 Harrison $(1969$, p. 45). On the history and meaning of the word socialism see Gide and Rist (1915, p. 263), Beer (1940), Bestor (1948) and Landauer (1959). Honneth (2017, p. 607) noted that sozialistisch was used in German in the late eighteenth century with a very different meaning. It referred to a doctrine in jurisprudence that gave natural law a secular foundation.

6 Owen (1991, p. 362). 
Pillot. Influenced by Owen, Cabet was a Christian advocate of utopian communist communities. Dezamy and Pillot were admirers of the French revolutionary Gracchus Babeuf, who plotted the revolutionary abolition of private property and the installation of common ownership, before his execution in $1796 .^{7}$

Carrying a letter of introduction from Owen, John Goodwyn Barmby went to Paris in 1840 to meet the advocates of le communisme. On his return, Barmby founded the London Communist Propaganda Society in 1841 and established the Communist Chronicle newspaper. Despite his close working links with the Owenites, Barmby criticized socialism because 'it wants religious faith, it is too commercial, too full of the spirit of this world, and therefore is rightly damned'. Communism for him was less materialistic and more divine. With the investment of these idiosyncratic spiritual connotations, Barmby imported the word communist into English. It spread in the UK and the US, where the term socialist was already prominent. The word Kommunist had appeared in German by 1842, when Marx noted its usage. ${ }^{8}$

Barmby's attempt to align communism with religion proved unsuccessful. But he was influential for a while. He alerted Engels to the French communiste movement. In 1843 Engels reported to the Owenite journal The New Moral World that there were 'more than half a million Communists in France' and that 'Communist associations' and individuals describing themselves as communists were plentiful in Germany, Italy, Switzerland and elsewhere. Engels addressed his Owenite readers as 'English socialists' and saw them as having very similar aims to the Continental communists. ${ }^{9}$

In the second (1849) and later editions of his Principles of Political Economy, John Stuart Mill noted another early difference of meaning between socialism and communism. For followers of Saint-Simon or of Fourier in France, communism meant 'the entire abolition of private property', whereas socialism was 'any system which requires that the land and the instruments of production should be property, not of individuals, but of communities or associations, or of the government'. Unlike communism, this meaning of socialism would allow for individual ownership of personal possessions. Hence Mill described Owenism as

7 Bestor (1948, p. 280), Hodgson (2018, pp. 37-8, 40, 43-4, 227).

8 Bestor (1948, p. 280), Harrison (1969, p. 175), Marx and Engels (1975a, pp. 21521), Taylor (1983, pp. 172-82, with the Barmby quote on p. 174). The Communist Propaganda Society was later renamed the Communist Church, but that folded in 1849. Barmby and his wife Catherine campaigned for female suffrage. Barmby later abandoned communism and became a radical Unitarian minister.

9 Marx and Engels (1975a, pp. 392-408, 414). 
communism, because it upheld the abolition of all private property. But this particular distinction in meaning between the two words was forgotten after the Saint-Simonian, Fourierist and Owenite experiments faltered. ${ }^{10}$

Perhaps more influentially, the 1848 edition of Webster's American Dictionary defined socialism as a 'social state in which there is a community of property among all the citizens', and defined communism as 'a new French word, nearly synonymous with ... socialism'. ${ }^{11}$

Hence both socialism and communism referred to the abolition of (most or all) private property and the establishment of common ownership of the means of production. Slight differences of meaning were proposed by Barmby (who made communism more religious and spiritual) and Mill (who understood communism to mean the abolition of all - even personal - private property). But these early nuances of difference did not endure. Henceforth the two terms became entwined within Marxism, there to perform an entirely different dance of meaning.

\section{MARXISM, COMMUNISM AND SOCIALISM}

Marx and Engels often treated the terms socialism and communism as interchangeable. But occasionally they gave them different nuances. In 1845 they used the new word communism as their label for their movement: 'Communism is not for us a state of affairs which is to be established, an ideal to which reality [will] have to adjust itself. We call communism the real movement which abolishes the present state of things.' When they henceforth started setting up political organizations they adopted and promoted the term communist rather than socialist. But their ultimate goals were the same as most socialists at the time. ${ }^{12}$

In 1888 Engels explained why he and Marx had chosen the word Communist for their famous Manifesto of 1848. Engels claimed that the word socialism was then too 'respectable' and too 'middle class'. He wrote:

Yet, when it was written, we could not have called it a 'Socialist' manifesto. By 'socialists', in 1847, were understood, on the one hand, the adherents of the various utopian systems: Owenites in England, Fourierists in France, both of them already reduced to the position of mere sects, and gradually dying out; on the other hand, the most multifarious social quacks ... in both cases

10 Mill (1909, pp. 205-206, 772).

11 Bestor (1948, p. 263).

12 Marx and Engels (1976a, p. 49). 
men outside the working-class movement ... Whatever portion of the working class had ... proclaimed the necessity of a total change, that portion then called itself communist. ... Thus, socialism was, in 1847 a middle-class movement, communism a working-class movement. ${ }^{13}$

Engels omitted to note that the self-described communists in the $1840 \mathrm{~s}$ also had more than their fair share of middle-class devotees, quacks, bizarre utopians and radical clerics. Engels himself had noted in 1843 that the 'half a million Communists in France' were led by the Catholic priest Cabet, who promoted his own dream of a communist utopia. ${ }^{14}$

It is possible that Marx and Engels adopted the term communist partly because it had become more popular in a Continental Europe on the eve of the 1848 revolutions. While socialism remained more widespread in Britain, the Owenite movement, with which it was largely associated, had already passed its peak by 1847 . While the younger term communism had already attracted several oddballs in the seven years of its use, socialism had the additional negative legacy of numerous failed utopian experiments in the 1820 s and 1830 s, in the UK and the US. ${ }^{15}$

Instead of small-scale utopian experiments, Marx and Engels favoured a global insurrectionary strategy. As Engels observed in 1843, the French communists understood the need for 'meeting force by force ... having at present no other means'. Marx and Engels chose the word communism in the 1840s, not because their goal was different from socialism, but partly because many self-described communists in Continental Europe promoted armed insurrection. The penultimate section of the Communist Manifesto attacks various strands of socialism, not for their collectivist goals, but for their impractical strategies and their failure to countenance the use of force. The final paragraph of the whole work drives the point home: 'The Communists ... openly declare that their ends can only be attained by the forceful overthrow of all existing conditions.' 16

But a few decades later, the word socialism was again in the ascendant. In 1880 Engels published Socialisme utopique et socialisme scientifique in the French Revue socialiste: notably he put socialisme rather than communisme in the title. By 1890 a number of parties describing themselves as socialist or social-democratic had taken root in Germany, France and elsewhere. In 1895, Engels wrote approvingly of 'the one great international army of Socialists, marching irresistibly on and

\footnotetext{
13 Marx (1973, pp. 64-5).

14 Marx and Engels (1975a, pp. 392, 397-400), Erasmus (1977, pp. 111, 201, 205-19,

15 Harrison (1969), Hodgson (2018, pp. 70-73) and Chapter 3 of this book.

16 Marx and Engels (1975a, p. 398), Marx (1973, p. 98).
} 264). 
growing daily in number'. The earlier emphasis on physical force was also reduced: the possibility of achieving their goal by democratic means, rather than by insurrection, seemed greater than before. One of the major reasons for using the term communism rather than socialism had disappeared. ${ }^{17}$

William Morris was an artist, craftsman and writer, and one of the first English intellectuals to embrace Marxism. Writing in a 1903 Fabian Tract, he saw socialism and communism as virtual synonyms: 'between complete Socialism and Communism there is no difference whatever in my mind'. They assert that the means of production and the resources of nature 'should not be owned in severalty, but by the whole community'. ${ }^{18}$

Whether they used the term socialism or capitalism, their fundamental aim was clear. In the Communist Manifesto, Marx and Engels echoed Owen and called for the 'abolition of private property'. They proclaimed an economic order in which 'capital is converted into common property, into the property of all members of society'. Engels repeated in 1847: 'The abolition of private ownership is the most succinct and characteristic summary of the transformation of the entire social system ... and ... is rightly put forward by the Communists as their main demand.' In 1850 Marx and Engels again declared: 'Our concern cannot simply be to modify private property, but to abolish it'. ${ }^{19}$

This meant the complete abolition of markets. They wanted an end to the 'free selling and buying' of commodities. As Marx wrote in 1875: 'Within the cooperative society based on common ownership of the means of production, the producers do not exchange their products'. Engels argued in 1884 that "no society can permanently retain the mastery of its own production ... unless it abolishes exchange between individuals'. The abolition of markets was seen as necessary for social control. ${ }^{20}$

By emphasizing national ownership, Marx and Engels went much further than Owen and most other early socialists or communists. Marx and Engels welcomed efforts 'to centralize all instruments of production in the hands of the state' and looked forward to a time when 'all production has been concentrated in the hands of a vast association of the whole nation'. ${ }^{21}$ Engels explained in 1847:

\footnotetext{
17 Marx and Engels (1962, vol. 1, p. 125).

18 Morris (1973, p. 234).

$19 \operatorname{Marx}$ (1973, pp. 80-81, 324), Marx and Engels (1976b, p. 348).

20 Marx (1973, pp. 81-2), Marx (1974, p. 345), Marx and Engels (1962, vol. 2, p. 267).

21 Marx (1973, pp. 86-7).
} 
[The] new social order ... will have to take the running of industry and all branches of production in general out of the hands of separate individuals competing with each other and instead will have to ensure that all branches of production are run by society as a whole ... according to a social plan and with the participation of all members of society. ${ }^{22}$

Described as either communism or socialism, this utopia of national ownership and 'social' control persisted in their writings. It appeared, for example, in the second volume of Capital in which Marx wrote of the planned system of 'social production' where 'society distributes labourpower and means of production between the various branches of industry'. In one of his last manuscripts, written in 1880, Marx remarked that in the society of the future "the "social-state" will draw up production from the very beginning ... The scope of production ... is subject in such a state to rational regulation.' ${ }^{23}$

In his Critique of the Gotha Programme of 1875, Marx used the term communism to describe his goal. He considered 'the first phase of communist society as it is when it has just emerged after prolonged birth pangs from capitalist society'. Eventually a new order would follow:

In a more advanced phase of communist society, when the enslaving subjugation of individuals to the division of labour, ... when the all-around development of individuals has also increased their productive powers and all the springs of cooperative wealth flow more abundantly - only then can society ... inscribe on its banner: From each according to his abilities, to each according to his needs! 24

Hence Marx considered a 'first phase' and then a 'more advanced phase' of communism. Writing in his State and Revolution in August 1917, Lenin referred to this passage from Marx's Critique of the Gotha Programme but introduced a different usage. He wanted to defend the planned Bolshevik seizure of power against the criticism that Russia was insufficiently developed economically for a radical Marxist revolution.

Lenin amended the Marxist dictionary and renamed Marx's 'first phase of communist society' as socialism. Under this socialism the means of production would be in public ownership but there would still be a struggle against bourgeois ideas and material shortages. When that struggle was completed, and after the subjugation of 'capitalist habits',

\footnotetext{
22 Marx and Engels (1976b, p. 348).

23 Marx (1978, p. 434), Marx (1976b, p. 207), Ollman (1977) and Campbell (2011).

$24 \operatorname{Marx}(1974$, p. 347).
} 
full communism would be established. 'The whole of society will have become a single office and a single factory with equality of labour and pay. ${ }^{25}$

In contrast, Marx and Engels never distinguished the terms socialism and communism in this way. For them, socialism and communism both meant the abolition of the private ownership of the means of production. They wrote of lower and higher 'phases' but did not use different nouns to distinguish them.

The Socialist International (also known as the Second International) was a global association of socialist parties, formed in 1889. In 1919, Lenin and the Bolsheviks broke from the Socialist International and formed the Communist International (also known as the Third International). The difference between the Communist and Socialist Internationals was not stated in terms of ultimate objectives. Instead the Communist International was formed because several parties in the Socialist International had supported their national governments in the First World War. There was no declared amendment of final goals, although leaders of the Second International were accused of de facto abandoning socialism.

\section{SMALL SOCIALISM - INHIBITED BY AGORAPHOBIA}

While Owen and other early socialists focused on communities of no more than a few thousand members, Marx and Engels envisaged public ownership and planning at the national level. This divided socialist thought, between those that cherished the autonomy of local collective ventures and those who sought the 'rational' organization of production on a national scale.

Owen and others did not explain clearly in their writings how autonomous socialist communities would relate to each other. Would they be economically independent, or would they be allowed to trade with each other? Complete isolation and independence would come at a price: everything would have to be produced from within, without reaping the benefits of lower costs due to the higher productivity of a broader division of labour.

Alternatively, these socialist communities could sell to and buy from other enterprises, whether they were cooperatives, sole traders or conventional private firms. If they were not to be isolated and independent, then they would have to trade on markets. The question of whether socialist

\footnotetext{
25 Lenin (1967, vol. 2, pp. 337-45).
} 
communities were allowed to trade on markets was an enduring ideological dilemma for small-scale socialists.

Philippe Buchez was a follower of Saint-Simon. He promoted workerowned cooperatives as early as 1831. Originally, he argued that these cooperatives should merge into a single 'universal association'. But eventually, and contrary to most contemporary socialists and communists, Buchez and his followers recognized the need for multiple, autonomous, worker cooperatives. To be autonomous, they needed rights to trade on markets. ${ }^{26}$

Because Buchez resisted national amalgamation and centralization, his ideas were explicitly rejected by Marx and Engels. Hence Marx in 1875 described Buchez's ideas as 'reactionary', 'sectarian', opposed to the workers' 'class movement', and contrary to the true revolutionary aim of 'cooperative production ... on a national scale' ${ }^{27}$

In 1840 Pierre-Joseph Proudhon suggested a similar system of independent worker cooperatives that could freely enter into contracts. He proposed 'mutualist associations' of groups of workers who would pool their labour and their property, holding these resources in common. To distance themselves from the statist socialism of Marxists and others, Proudhon and his followers often described their philosophy as anarchism. ${ }^{28}$

Many socialists like cooperatives, but they dislike markets. They may support independent cooperatives, believing eventually they should merge. But if cooperatives lose the right to own and trade their property, then they lose much of their devolved power. This point is lost on many. Socialists who are opposed to markets effectively rule out genuinely autonomous worker cooperatives.

An anti-market mentality prevails among socialists. Advocates of central planning eschew markets and their alleged ills. Hence the Marxist economist Maurice Dobb objected to market socialism because it introduced 'the Trojan horse of a capitalist market mechanism into the citadel

26 Gide and Rist (1915, p. 258) and Reibel (1975). Davis and Parker (2007) argue that Thomas Hodgskin, William Thompson and John Francis Bray proposed cooperatives coordinated by markets in the 1820 s and 1830 s.

27 Marx (1974, pp. 353-4). Marx saw the propaganda advantages of worker cooperatives. They could show that workers were capable of managing production themselves. In his draft 'Inaugural Address of the International Working Men's Association' of 1864, Marx (1974, p. 80) praised the established producer cooperatives, but did not see them as having an autonomous future under socialism. Instead, he saw their salvation in their development 'to national dimensions ... fostered by national means'. Marx proposed that all worker cooperatives would amalgamate into nationalized industries.

28 Proudhon (1969). 
of socialist planning' ${ }^{29}$ There is a widespread view that markets foster competition, encourage greed, and lead to inequality and exploitation. Hence markets must be abolished. Many socialists suffer from agoraphobia - literally a fear of markets.

As Noel Thompson reported in his study of nineteenth-century socialism: 'The market was anathematised by almost all nineteenth century socialist writers.' Among the exceptions were John Ruskin and some of the Christian socialists. Even Fabian socialists had an 'ultimate vision of a fully planned and consciously controlled socialist economy' where markets were gradually marginalized to insignificance. Thompson concluded that 'the consequences of this determination to abandon the market were little short of disastrous for the subsequent evolution of socialist economic thinking'.30

There is a persistent view among socialists that markets should eventually be completely abolished. Tony Benn - a former Labour Cabinet minister in the UK - argued (rather vaguely) that 'market forces' should be opposed. Similar views are found among socialist academics. Michael Albert wrote: 'I am a market abolitionist. I know markets are going to be with us for some time to come, but I also know - or hope that in time we will replace them entirely.' Robin Hahnel, a professor of economics at Portland State University, similarly upheld a vision of a market-less economy: 'I do not believe that markets have any role to play in a truly desirable economy ... our long run goal should be to replace markets entirely with some kind of democratic planning.' Bertell Ollman, a Marxist professor at New York University, also supported 'doing away with private ownership and market exchanges completely'. ${ }^{31}$

The influential Marxist and 'critical realist' philosophers Roy Bhaskar and Andrew Collier supported 'a form of socialism which is neither a market economy nor a command economy nor a mix of the two, but a genuine extension of pluralistic democracy into economic life'. The socialist philosopher John O'Neill claimed to 'puncture the case for a market economy' and argued for the money-less, market-less, international associationism, as sketched in outline by the socialist philosopher Otto Neurath. ${ }^{32}$

The endurance of agoraphobia helps to explain why big socialism has proved more popular than small socialism. The battle between these "two

\footnotetext{
29 Dobb (1969, p. 188).

30 Thompson (1988, pp. 281, 284, 285).

31 Benn (1979, 1981, 1982), Albert (2004), Ollman (2004), Hahnel (2005, 2007, p. 1157).

32 Bhaskar and Collier (1998, p. 392), O’Neill (1998, pp. 176-7).
} 
cultures' within socialism erupted in 1977 within the Socialist Party of France. The 'two cultures' approximate to what are described here as big socialism and small socialism. Michel Rocard led a group within the Socialist Party that criticized the centralist excesses of the statist socialism. Instead he proposed worker-owned, self-managed cooperatives, all trading within a market economy.

Rocard was then attacked for 'abandoning the very foundations of socialism and adopting fashionable individualist themes, imported from the USA'. ${ }^{33}$ Today the critic would have accused Rocard of neoliberalism.

From 1988 to 1991 Rocard served as French Prime Minister under President François Mitterrand. Later Rocard remarked that 'the Socialist Party was born in 1905 with a doctrinal ambiguity that was never resolved: it still does not know whether it should accept the market economy or if it wants to smash it'. ${ }^{34}$

Emmanuel Macron was a protégé of Rocard. Macron broke from the Socialist party, partly because it was unable to overcome its congenital agoraphobia. Widely but misleadingly described as a neoliberal by the traditional Left, Macron founded a new party and was elected President of France in 2017.

\section{NON-MARXIST SOCIALISM IN THE UK LABOUR PARTY}

From the 1870 s to the present day, big socialism has retained the upper hand over small socialism, among non-Marxists as well as Marxists. The majority of socialists argued for a system of comprehensive national planning based on widespread public ownership. Socialists differed more on strategy than on their goals. Some argued for gradual change, focusing on parliament. Others promoted insurrectionary violence to seize power. But almost all socialists agreed on widespread public ownership - for socialists this goal was ubiquitous, with few exceptions.

In the year that he first became Labour Prime Minister, Harold Wilson famously wrote that British socialism 'owed far more to Methodism than to Marx'. While rightly underlining the importance for socialism of Christianity in general and Methodism in particular, this statement underestimates the influence of Marx upon British thought and vice versa. But even more seriously, it overlooks the fact that state socialism

\footnotetext{
33 Berstein (2003, p. 171) - translated by the present author.

34 Reuters (2007) - translated by the present author.
} 
was largely a Marxist invention, and notions of big socialism became dominant in the Labour Party. ${ }^{35}$

George Bernard Shaw was a leading Fabian. Although he was not a Marxist, in 1890 he wrote with approval: 'Socialists are trying to have the land and machinery "socialised," or made the property of the whole people'. Almost forty years later he explained in his entry on 'socialism' in the Encyclopadia Britannica: 'Socialism, reduced to its simplest legal and practical expression, means the complete discarding of the institution of private property by transforming it into public property'. By that time, Shaw had become an admirer of the Soviet Union under Joseph Stalin. ${ }^{36}$

James Keir Hardie was another Fabian socialist and he was elected to the UK parliament in 1892. He became one of the founders of the Independent Labour Party in 1893. Two years later, Hardie wrote about his socialist views and the manifesto of this party: 'State socialism is necessary ... Our platform is the creation of an industrial commonwealth upon the socialisation of land and capital. ${ }^{37}$

In 1900 Hardie organized a historic meeting of various trade unions and socialist groups and they agreed to form a Labour Representation Committee. Its aim was to elect more working-class representatives to Parliament. In 1906 this was renamed the Labour Party and Hardie was elected as its leader. Although this party was devoted to obtaining power through parliament, its aim of widespread common ownership was equivalent to that of other socialists and communists. The first leader of the British Labour Party believed in big socialism, entailing widespread state ownership. In 1908 the Labour Party Conference passed a resolution, adopting the aim of 'the socialization of the means of production, distribution and exchange to be controlled by a democratic state'. ${ }^{38}$

The philosopher Bertrand Russell stood as a Labour Party candidate in the 1922 and 1923 general elections. He wrote in 1918: 'I think we shall come nearest to the essence of Socialism by defining it as the advocacy of communal ownership of land and capital. Communal ownership may mean ownership by a democratic State, but cannot be held to include ownership by any State which is not democratic.' Russell wrote similarly

\footnotetext{
35 Wilson (1964, p. 1).

36 Shaw (1890, p. 3), Shaw (1930, p. 3), Minney (1969) and Hollander (1998).

37 Hardie (1895).

38 The quotation is cited in Miliband (1961, p. 27). While the Labour Party's ideology was influenced more by Christ than by Marx, it is important not to ignore the sway of the latter. Hardie (1910, p. 13) wrote: 'The Labour Party is the only expression of orthodox Marxian Socialism in Great Britain. ... The Labour Party practices the Marxian policy of class struggle, following Marx's own example.'
} 
in 1924: 'Socialism ... means the common ownership of land and capital, together with a democratic form of government.' 39

When defining socialism, Russell added democratic government to common ownership..$^{40}$ Hence, contrary to many socialists at the time, he did not regard the Soviet Union as socialist. But Russell did not consider the possibility that the concentration of ownership and economic power in the hands of the state would inevitably undermine political democracy. No regime in history has combined large-scale common ownership with democratic government. Lenin promised in 1917 that the Bolshevik revolution would bring a vast expansion of democracy. But it turned out differently: the logic of big socialism undermines the socio-economic basis of democracy, irrespective of the aspirations or priorities of the leaders.

The highly influential Fabian socialists Sidney and Beatrice Webb had an ultimate vision of a fully planned economy where all markets and private ownership of the means of production were gradually marginalized to insignificance. Eventually, they wanted all private ownership of the means of production to be ended: it was a 'perversion'. They envisaged a massive, complex structure of national, regional and local committees, all involved in decision-making over details of production and distribution: 'What we wish to substitute for the present chaos is systematic co-ordination'. In 1924 Sidney Webb summarized his view of socialism as involving '(1) Collective Ownership; (2) Collective Regulation; (3) Collective Taxation; and (4) Collective Provision - the whole under the direction of Democracy, industrial and political.' Like Shaw, the Webbs became devotees of the Soviet Union under Stalin. ${ }^{41}$

\footnotetext{
39 Russell (1918, p. 1), Griffiths (1924, p. 66).

40 Michael Harrington was highly influential in the Democratic Socialist Organizing Committee and in its successor, the Democratic Socialists of America (DSA). Harrington $(1972,1989)$ insisted that socialism by definition must be democratic. Harrington (1989, p. 9) argued that capitalism itself is becoming more centralized and planned - and hence 'socialized' in his use of the term. For him, socialism meant taking power and putting that process under the 'democratic control' of the people. Both the 1972 and 1989 books attempt to rehabilitate Marx's politics, without understanding that his vision of nationally agglomerated economic power would destroy the separation of multiple politico-economic powers upon which democracy depends (Moore, 1966; Galbraith, 1952, 1969; North et al., 2009). He also fudges the question of how democratic socialism would be organized, and how resources would be valued and allocated, especially after money is 'abolished' (Harrington, 1972, pp. 421, 423, 449, 453-6).

41 See Webb and Webb (1920, pp. 200, 342-3), Griffiths (1924, p. 80) and Webb and Webb (1935). M. Polanyi (1940, pp. 96 ff.) published a scathing review of the Webbs' apologia for the USSR.
} 
The Webbs drafted the 1918 Constitution of the British Labour Party. Its aims included the famous Clause Four, Part Four:

To secure for the workers by hand or by brain the full fruits of their industry and the most equitable distribution thereof that may be possible upon the basis of the common ownership of the means of production, distribution and exchange, and the best obtainable system of popular administration and control of each industry or service.

This allowed for no exception: all production would be in common ownership and there would be no private sector. The inclusive term common ownership satisfied both statist socialists and those who favoured other forms of common ownership, such as worker cooperatives. Big socialism and small socialism were both skilfully accommodated. Proponents of a mixed economy were not.

J. Ramsay MacDonald became the first-ever Labour Prime Minister. He led short-lived Labour minority governments in 1924 and 1929-31. He saw socialism as 'a movement to supplant Capitalism altogether, by organising communally the services which Capitalism performs or ought to perform'. He referred to 'the simple Socialist idea of communal responsibility for production and distribution'. The task of socialists was 'to transform a state of society in which capital controls labour and industry into one in which labour and industry control capital'. While stressing communal organization and control, his formulation was also consistent with wholesale common ownership. ${ }^{42}$

In 1923 Philip Snowden proposed the key motion in the famous 'socialism versus capitalism' debate in the UK House of Commons. This motion found the roots of economic failure 'in the private ownership and control of the means of production and distribution'. The motion called for 'an industrial and social order based on the public ownership and democratic control of the means of production and distribution'. This debate was wound up by MacDonald, who spoke in favour of the motion. It was defeated by 368 votes to 121 . Labour had 142 seats at the time, and there were two Communist Party MPs, who presumably were among the 121 . This suggests that about 84 per cent of the Parliamentary Labour Party voted in favour of (what could be interpreted as) 100 per cent public ownership. Snowden became the first-ever Labour Chancellor of the Exchequer in $1924 .{ }^{43}$

\footnotetext{
42 MacDonald (1921, pp. 37, 242, 278).

43 Griffiths (1924, p. ii).
} 
Dan Griffiths was a schoolteacher in Wales and an active member of the Labour Party. He asked several leading British socialists to provide their definition of socialism. He received 199 publishable responses, from writers, academics, trade unionists and 59 Members of Parliament. His respondents included Clement Attlee, Fenner Brockway, G.D.H. Cole, Maurice Dobb, George Lansbury, Harold Laski, J. Ramsay MacDonald, Herbert Morrison, Bertrand Russell, Emanuel Shinwell, Philip Snowden, Sidney Webb and H.G. Wells.

Many offered sentiments or platitudes rather than clear guidance on meaning. Some interpreted his question as a request for a statement of socialist values. Others outlined what they meant by a socialist system. Several respondents saw socialism as the expression of Christian teaching. A few others were Marxists.

Notwithstanding many vague answers, as many as 85 of the 199 respondents saw socialism as bringing most or all of the means of production under some form of common ownership. This was the most prominent relevant attribute among the responses. Seven further respondents saw socialism as involving a significant public sector. Only two respondents accepted explicitly that some form of private enterprise could remain under socialism. No respondent mentioned any surviving role for competition or markets under socialism. While several respondents saw socialism primarily in terms of personal attitudes, ideals or values, none explicitly denied common ownership as a vital end or means.

For 24 respondents, socialism meant the extension of democracy from the political to the economic sphere; 77 respondents highlighted cooperation, often explicitly opposed to competition; 39 stressed production for use rather than for profit; 25 highlighted greater equality in wealth or opportunity. ${ }^{44}$

The survey by Griffiths shows definitively that socialism, in so far as it was defined at all, was widely (at least in the UK in the 1920s) understood as common ownership of the means of production. Among these prominent socialist politicians, intellectuals and trade unionists there was no significant support for a mixed economy and there was a complete failure to mention or defend any role for markets or the private sector.

Significantly, for Herbert Morrison, socialism meant: 'Ownership by public authorities of land and the essential means of industrial production

44 Griffiths (1924). 
and distribution'. ${ }^{45}$ Morrison became Minister of Transport during the 1929-31 Labour Government, Home Secretary in the wartime coalition of 1940-45 and Deputy Prime Minister in the Labour Government of 1945-51. He also served for a few months as Foreign Secretary before Labour's defeat in 1951. During the 1945-51 Labour Government, Morrison developed his model of the public corporation as a key form of public ownership. ${ }^{46}$

The Fabian G.D.H. Cole was an influential Labour Party theoretician and known as one of the famous three 'red professors', alongside Harold Laski and Richard Tawney. Cole taught Harold Wilson at Oxford, who became a Labour Prime Minister from 1964 to 1970 and 1974 to 1977. Cole was a pioneering advocate of 'guild socialism'. He saw the guilds as part of a system of national planning. He sought an integrated, national system where:

a single authority is responsible both for the planning of the social production as a whole and for the distribution of the incomes which will be used in buying it. In other words, the remedy is some sort of Socialism - involving the socialisation of the essential means of production, distribution and exchange. ${ }^{47}$

In 1937 Clement Attlee wrote of the 'evils' of capitalism: their 'cause is the private ownership of the means of life; the remedy is public ownership'. Attlee then approvingly quoted the words of Bertrand Russell: 'Socialism means the common ownership of land and capital together with a democratic form of government. ... It involves the abolition of all unearned wealth and of all private control over the means of livelihood of the workers.' Apart from the exceptions noted above, the word socialism endured from the 1830 s to the 1950 s with these strong collectivist connotations, in opposition to private firms and markets. ${ }^{48}$

As Labour Prime Minister from 1945 to 1951, Attlee combined a measure of socialist idealism with an overriding pragmatism. Under his government, several industries were taken into public ownership, including the railways, coal, gas, steel, electricity and telecommunications. The National Health Service was founded in 1948, with strong Liberal involvement and Conservative tolerance. But with the outbreak of the

\footnotetext{
45 Griffiths (1924, p. 55).

46 Foote (1997, pp. 174-82).

47 Cole $(1935,1948$, p. 101). For evidence that Cole limited the autonomy of the guilds and saw them as subservient to the national plan see Cole (1935, pp. 332-4, 338) as quoted in Chapter 2 below.

48 Attlee (1937, pp. 15-16).
} 
Cold War in 1948, the Attlee government chose the side of Western capitalist democracies and NATO against Soviet Communism.

Although some Labour Party thinkers eventually began to entertain the possibility of some private enterprise in their future society, many party members remained resolutely in support of widespread common ownership. The UK Labour Party did not formally abandon its Clause Four commitment to the complete 'common ownership of the means of production, distribution and exchange' until 1995.

\section{REVISIONIST ATTEMPTS TO SHIFT THE MEANING OF SOCIALISM}

The term revisionist was applied to, and willingly accepted by, the prominent German socialist Eduard Bernstein. This was not because he abandoned or modified the socialist goal, although he was suspected by his severest critics of doing so. In his 1899 book Evolutionary Socialism, Bernstein accepted that socialism meant 'a society based on the principle of association' involving 'the socialisation of production and distribution' ${ }^{49}$

Bernstein was called a revisionist because he argued that the transition from capitalism to socialism could be gradual: it would be driven by democratic reform rather than by insurrection. Bernstein argued that socialists should concentrate on positive and peaceful incremental change using democratic means, rather than by revolutionary leaps toward utopia. It is testimony to the tenacity of the original socialist goals that the famous early revisionist controversies concerned the path to socialism, not the final objective.

But others appropriated the name socialism for different purposes. Adolf Hitler founded the National Socialist German Workers' Party in 1920. Its name was chosen to draw support from the working class, who were strongly influenced by social democratic, socialist and communist ideas, as well as from anti-Semitic nationalism. For the Nazis, race was more important than social class. They rejected the goal of widespread common ownership and maintained a capitalist mixed economy, albeit under heavy state regulation and control. The Nazi adoption of the term socialism was a cynical propaganda ploy. ${ }^{50}$

The sources of a more genuine revisionism lie elsewhere. In a book published in 1909 when he was a member of the Liberal Party, Hobson

49 Bernstein (1961, pp. 96, 100).

50 Nolte (1965), Gregor (1974), Evans (2003, 2006). 
favoured nationalization of the more routinized and standardized industries, but also made a case for retaining innovative and dynamic sectors in private hands. Principally because of his opposition to UK participation in the First World War, Hobson left the then-governing Liberal Party in 1916. He joined the Independent Labour Party in 1919. But he never swallowed socialism whole. He 'never felt quite at home in a body governed by trade union members and their finance, and intellectually by full-blooded Socialists'. In his 1932 pamphlet From Capitalism to Socialism he argued 'for a limited as against a complete socialism' and for partial not complete public ownership. Hobson's radical revisionism was for a mixed economy with 'socialist' components. ${ }^{51}$

Hobson influenced the Labour politician Douglas Jay. In his book The Socialist Case, first published in 1937, Jay echoed Hobson and advocated a mixed economy, along with redistributive taxation to alleviate economic inequality and Keynesian demand management. Jay also argued that the meaning of socialism should be changed from common ownership to the abolition of unearned incomes. Hobson welcomed Jay's book in a review in the Manchester Guardian. But Jay's cautious and much-qualified defences of markets and consumer choice drew much criticism from other leading figures in the Labour Party. G.D.H. Cole castigated the 1937 volume because it was not socialist enough: Jay had shown insufficient devotion to nationalization. ${ }^{52}$

Eventually Jay recoiled from his 1937 position. During the Second World War he developed a more positive view of national planning. In 1947, after Jay had become a Labour MP, a revised edition of The Socialist Case appeared with an approving Foreword by Prime Minister Attlee. But Jay still argued that "we must define socialism as the abolition of private unearned or inherited incomes rather than of the private ownership of the means of production'. 53

Although this definition would allow some privately owned firms, it would mean the end of all incomes from private ownership of rented land or homes, from financial institutions and from shares in corporations. For Jay, ending inheritance and unearned income meant "not merely nationalization of the banking system but direct public control of investment and of the whole range of public works'. He called for 'the transfer of property claims and unearned incomes to the state' and 'public ownership

51 Hobson (1909; 1932, p. 36; 1938, p. 125). In the 1920s and 1930s, Hobson tried to build bridges between socialism and liberalism (Clarke, 1978; Allett, 1981; Townshend, 1990).

52 Jay (1937, 1947), Durbin (1985, p. 150), Toye (2002).

53 Jay (1947, p. 194). 
as well as control in all cases where the search for private profit clearly conflicts with the basic human needs of the community'. Hence socialism would still 'extend public ownership and democratic control steadily throughout economic life'. Socialism 'in its original meaning of collective ownership and collective control, is a ... true description of what we mean'. Jay's adjusted definition of socialism kept the traditional emphasis on comprehensive planning and on extensive public ownership, but it provided a rationale for a small private sector. Nevertheless, this minimal acceptance of private enterprise was too much for many socialists, who still regarded him as a rightist and a revisionist. ${ }^{54}$

In the UK, reasoned revisionism found a bigger audience with the onset of the Cold War in 1948 and especially after Labour's 1951 election defeat. But strong and eloquent voices still defended traditional socialism. Aneurin Bevan was Labour Minister of Health when the UK National Health Service was founded in 1948. He warned in 1952 of the 'danger' of 'Fresh Thinkers' and of 'Socialist Revisionists': 'They suggest that an extension of public ownership is an old-fashioned and outmoded idea. ... It is essential that we should keep clear before us that one of the central principles of socialism is the substitution of public for private ownership. There is no way around this.' 55

Bevan became the popular leader of the traditional-socialist wing of the Labour Party, against the growing attempts by 'revisionists' to dilute the mission of their movement. Bevan insisted that the 'substitution of public for private ownership' must prevail.

Then, in 1956, C. Anthony Crosland published The Future of Socialism. He called for a more radical redefinition of socialism. He proposed new priorities in the face of capitalist economic growth and rising standards of living. For Crosland, public ownership was a means not an end. The true ends of socialism were greater economic equality and a welfare state that catered for basic human needs. This revisionism went much further than its predecessors. ${ }^{56}$

The original socialists believed that common ownership was the only way to reduce greed, inequality and social deprivation. For them, common ownership was an end as well as a means. Crosland claimed that they conceived common ownership as a means towards other ends,

54 Jay (1947, pp. xiv, 196, 261, 262, 278). Foote (1997, pp. 194-9) and Tomlinson (2014, p. 35) noted Jay's designation as a 'revisionist' or 'rightist'.

55 Bevan (1952, p. 2).

56 Crosland (1956), Foote (1997, ch. 10). 
particularly welfare and equality of opportunity. He argued that capitalism had changed, and common ownership was no longer necessary to reach these goals.

Crosland's hermetic separation of means and ends is questionable. Means and ends interact with one another. In particular, if there is only one means to achieve a goal, then it would logically assume the status of an end as well. In practical circumstances a complete separation of means from ends is impossible. ${ }^{57}$

In effect, Crosland had abandoned classical socialism for a version of radical liberalism that emphasized greater economic equality and a strong welfare state. Foreshadowed by thinkers such as Thomas Paine and John Stuart Mill, Anglo-American liberalism had prioritized these solidaristic goals since the 1890s. They were advanced by liberals such as John A. Hobson, David Lloyd George, John Dewey, John Maynard Keynes, William Beveridge and Michael Polanyi.

But instead of embracing the liberalism label, words such as socialism and social democracy were ceremonially retained in post-war revisionist circles, while there was an increasing reconciliation with markets, private enterprise and a mixed economy. In 1959 in Continental Europe - in a nation itself divided by the Iron Curtain - the (West) German Social Democratic Party abandoned the goal of widespread common ownership. In the same year, Hugh Gaitskell tried to get the British Labour Party to follow this lead, but he met stiff resistance and he was forced to retreat.

Labour's token ideological commitment to 100 per cent common ownership was retained while its leaders pursued policies within a mixed economy. But this pragmatism still had to deal with Labour's ingrained neglect or distrust of private enterprise. The historian Richard Toye noted that the Labour Party, because of its enduring preference for public ownership, failed to develop adequate policies to support private enterprise: 'Labour, until at least the 1950s, showed little interest in developing policies for the private sector. During the 1960s, the party demonstrated continuing ambiguity about whether or not competition was a good thing. This ambiguity continued at least until the 1980s.' ${ }^{58}$

By working within a party that had adopted the classical definition of socialism since its inception, Labour Party revisionists were constantly

57 Dewey (1938, 1939), Hodgson (1988, pp. 93-7, 243, 285-6).

58 Toye (2004, p. 91). 
trying to make the leopard change its spots. The German Social Democratic Party abandoned widespread common ownership only when Germany was split in two opposing camps, and the East became part of the Soviet bloc.

\section{THE FAILURE OF REVISIONISM IN THE UK LABOUR PARTY}

In the UK, while the official doctrine remained unchanged and old habits of thought remained prevalent, it took a run of four successive and decisive election defeats - 1979, 1983, 1987 and 1992 - for the British Labour Party to elect as its leader a politician with the courage and perception to challenge the mantra of 100 per cent common ownership in Labour's official aims.

Tony Blair became leader in 1994. In a short pamphlet he expressed his support for what he called 'ethical socialism'. He claimed that the ethical socialists of the past saw 'socialism' as 'defined by certain key values and beliefs' and not by common ownership. But he failed to cite any sources to confirm this. The evidence in this chapter shows that he was wrong - socialism throughout its history has generally meant common ownership. ${ }^{59}$

Blair claimed to be influenced by the Christian socialist John Macmurray. But Macmurray was a classical socialist who argued that the state should 'assume control of the economic and financial activities of society', which was very far from Blair's own view. As one critic put it: 'gaping chasms can be identified between the positions of Macmurray and Blair on almost every issue on which the former pronounced'. Blair played fast and loose with the history of socialist ideas. ${ }^{60}$

Following Crosland, Blair argued that the emphasis on common ownership or nationalization confused means with ends. Social harmony and social justice could be achieved by other means. While rejecting the overriding commitment to the common ownership of the means of production, Blair promoted 'social-ism', by which he meant recognizing individuals as socially interdependent. For Blair it also signalled social

\footnotetext{
59 Blair (1994).

60 Blair (1982, 1994), Hale (2002, esp. p. 193), Kirkpatrick (2005, pp. 24, 39, 157), Hodgson (2018, pp. 113-16).
} 
justice, social cohesion, equal opportunities and the equal worth of each citizen. But again, all of these ideas were to be found in the liberal tradition. ${ }^{61}$

For Blair, social-ism is about attitudes and values, rather than institutional arrangements or modes of property ownership. It is true that ethical statements about values have always been prominent among socialists. But typically, their key values included a moral distaste for competition and for profit-making from private ownership of the means of production. Negative ethical judgements were attached to public or private ownership of property.

Blair argued differently. He wanted ethical values such as care and cooperation, but no moral evaluation of different systems of property ownership. This would allow a free hand over what institutional forms were favoured or developed, as long as some other 'core values' were preserved. For example, privatization of nationalized industries could occur, as long as 'social-ist' values of caring for others remained. His value-driven revisionism meant a socialism unbounded by constraints on the form of ownership, over the distribution of wealth or the structure of power.

This was a very radical move. How would it be possible to persuade the Labour Party to accept it? Interestingly, the 1918 version of Clause Four did not include the word 'socialism'. It mentioned 'common ownership' instead. Ironically, the revised version of 1995 declared for the first time: 'The Labour Party is a democratic socialist party.' Perhaps these words reassured many party members, despite the fact that Blair wanted to eviscerate them of much of their previous meaning.

Hence Clause Four ceased to promote unalloyed common ownership. Instead it admitted a positive role for markets and a private sector. The new version called for a 'dynamic economy' where 'the enterprise of the market and the rigour of competition are joined with the forces of partnership and co-operation' and 'a thriving private sector'. But old habits die hard. Socialist fundamentalists such as Benn wished to retain the original wording. Benn protested: 'Labour's heart is being cut out' ${ }^{62}$

The instigation of a 'democratic socialist' objective was a compromise for those who kept much of the old intellectual baggage but recognized

\footnotetext{
61 But Blair has made some remarks that are worryingly remote from liberalism. At his speech to the 1997 Labour Party conference Blair said that 'a decent society is not based on rights. It is based on duty' (British Political Speech, 2018). This is redolent of Tawney's (1921) unconvincing critique of unconditional rights. By contrast, liberals generally stress both rights and duties.

62 Rentoul (1995).
} 
that Labour's aims could be realized only through political power. For many, as R.T. Allen suspected, 'it is only the electoral failure of socialism that has motivated the creation of "New Labour" and not any appreciation of its intellectual and moral bankruptcy'. ${ }^{63}$

Instead of tackling the problem of Labour's old collectivist DNA more directly, Blair tried to change the meaning of socialism and to airbrush Labour's intellectual history. He failed to promote an adequate alternative vision to replace old-fashioned common ownership. To the traditional Left, it seemed that Blair wished to substitute capitalist compromise for cherished purity and socialist principle.

Inadvertently, Blair's endorsement of the word socialism gave legitimacy to those that defended socialism in its original meaning. The retention of the s-word played into the hands of the party's enduring, backward-looking Left. The 2003 invasion of Iraq helped to turn the Labour membership against Blair and his perceived compromises with capitalism and 'Western imperialism'. Collaboration with capitalism at war was seen as confirmation of Blairite 'neoliberal' collaboration with capitalism in peace. When Blair stepped down from office in 2007, he left a divided and ideologically rudderless party, which was soon to be shocked by a major crisis at the core of financial capitalism.

Eventually, as if there was an organization-level Freudian defence mechanism of developmental regression as a response to severe stress, Labour reverted to an earlier stage of its history, re-adopting its infant ideological comforts of collectivism and state control.

This theoretical, ideological and charismatic void explains why, by a large majority and with no strong rival, the Labour Party chose the retro-Marxist Jeremy Corbyn as its leader in 2015. He seized the enduring s-word in Labour's aims and claimed Labour's legacy. Classical socialism was back on the agenda. To many, Corbyn seemed to offer a new 'principled' approach to politics that broke with past compromises with capitalism. Classical socialism returned with a vengeance. Labour turned its ideological clock back to 1918 .

Revisionists have a difficult choice. They may try to change the meaning of the s-word or they may drop it entirely. Both options are tricky. Dropping the word would draw accusations of betrayal from the faithful. Alternatively, changing the common understanding of a word is a formidable task.

Words sometimes shift in meaning, but rarely by command. Language is a social process and we cannot successfully redefine words at will.

63 Allen (1998, pp. 2-3). 
Contrary to Humpty Dumpty in Alice through the Looking Glass, words cannot be used to mean anything that is intended by their user. Generally, such powers are not at the behest of an individual or group. We are part of an extensive linguistic community, engaged in multiple social processes that establish evolving commonalities of meaning and understanding. We are typically obliged to accept prevalent meanings. ${ }^{64}$

The attempts by Jay, Crosland, Blair and others to give the word socialism a modernized meaning have largely failed. The strategy of Sanders, to describe himself as a socialist but to avoid being tied down by a definition, assumes that many in his audience will not consult a dictionary. But the dictionaries testify that the original meaning endures. As the Merriam-Webster online dictionary put it, socialism means the 'collective or governmental ownership and administration of the means of production and distribution'. Nothing less.

Consequently, the word socialism still strongly connotes its original meaning, despite the passing of almost two centuries, with multiple revisionist efforts and the existence of rival usages. It is irresponsible to declare allegiance to socialism without taking this enduring baggage into account. Radical changes in the meaning of a word can only occur if there are strong forces of change behind them. Otherwise, words kick back - as they did for Labour in 2015.

\section{REVISIONISM WITH CHINESE CHARACTERISTICS}

Mao Zedong died in 1976. Despite some positive advances in education and elsewhere, his regime had also led to about 65 million deaths and mass poverty was still widespread. ${ }^{65}$ By 1978 the reforming wing of the Chinese Communist Party had gained power, under the leadership of Deng Xiaoping. He was bent on bringing his country out of centuries of poverty, and ending the economic disasters caused by reckless totalitarian direction from the centre.

Classical socialist doctrine clearly meant opposition to private enterprise and markets. Against this orthodoxy, Deng had to find a way of keeping the Communist Party activists on board. Consequently, he muted the meaning of socialism to mask its original opposition to private property and markets. Treating both planning and markets as possible means, not ends, Deng declared: 'The essence of socialism is liberation

64 Carroll (1970, pp. 268-70). On definitions generally see Hodgson (2019a).

65 Courtois et al. (1999). Higher estimates of the number of deaths are found in Rummel (1994). 
and development of the productive forces, elimination of exploitation and polarization, and the ultimate achievement of prosperity for all ... common prosperity is the essence of socialism.' Note the switch from 'property' to 'prosperity'. But if that is socialism, then we are all socialists now. 66

Deng's successful mobilization of platitudes opened the door to widespread markets, brought many millions of people out of poverty, and heralded explosive growth in the Chinese economy. China became a mixed economy, with an enduring strategic role for the state. Massive economic success allowed his revisionist change of meaning to endure.

To obfuscate their U-turn on markets and private ownership, official Chinese Communist Party documents today use terms like 'socialism with Chinese characteristics'. Appealing to national loyalty against enslavement to Western ideas is a clever rhetorical trick. But Marxism, Leninism, communism and socialism are all imports from the West.

In official doctrine, the eventual goal of communism with all property held in common is still preserved. Alongside revisionist formulations for the present, the old ideology has been retained for some unspecified occasion in the future. Hence the aims of the Communist Party of China still include the words: 'The realization of communism is the highest ideal and ultimate goal of the Party.' The intended meaning of communism here is unelaborated, allowing the Marxist faithful to retain the original meaning, while getting on with the business of building a capitalist economy and getting rich. ${ }^{67}$

Deng's revisionism made the word socialism a banality. This change of meaning could be sustained only because it opened the door for policies that led to a dramatic improvement in China's economic fortunes. At the same time, the future goal of full communism was retained for the faithful, even if many Chinese people ceased to believe in it. But of course, the future is always ahead: it never arrives. Such slippery formulations are possible in a one-party state, where there are the means to prevent people from asking too many awkward questions.

\footnotetext{
66 Deng (1992).

67 Communist Party of China (2013).
} 